\title{
The impact of Temperature on Development and Demographic Parameters of Tetranychus urticae (Koch)
}

\author{
M. A. Osman ${ }^{\star} ;$ A. A. Tawfik ${ }^{* *}$ and G. M. Abou-Elella ${ }^{* * \star}$ \\ *Agric. Zoology Dept., Faulty of Agric., Mansoura Univ., Mansoura, Egypt. mesoma20@mans.edu.eg \\ "Plant Protect. Rese. Institute, Agric. Res. Center, Dokki, Cairo, Egypt. \\ ${ }^{* * *}$ Pests and Plant Protec. Dept., National Research Center, Dokki, Cairo, Egypt
}

\begin{abstract}
Biological aspects and life table parameters of the two-spotted spider mite Tetranychus urticae Koch was determined at five temperature degrees. Total immatures averaged $8.30,7.50,6.85,5.15$ and 4.50 days, while life cycle averaged $14.95,12.95,10.50,7.65$ and 6.30 days for female when reared at $15,20,25,30$ and $35^{\circ} \mathrm{C}$, respectively. Life span averaged $35.40,31.00,20.50,15.30$ and 12.35 days at the same temperatures. The mean generation time (T) averaged $20.259,18.345,14.029,10.282$ and 8.775 days. The net reproductive rate $\left(R_{0}\right)$ values were $22.842,27.024,27.846$, 22.738 and 9.790 when $T$. urticae was kept at the same temperatures. The intrinsic rate of natural increase $\left(\mathrm{r}_{\mathrm{m}}\right)$ was $0.1543,0.179,0.237,0.303$ and 0.259 and the finite rate of increase (exp $r_{m}$ ) averaged 1.166, 1.196, 1.267, 1.355 and 1.296 at $15,20,25,30$ and $35^{\circ} \mathrm{C}$, respectively.
\end{abstract}

Key Words: Tetranychidae, Tetranychus urticae, Biology, Life tables.

\section{INTRODUCTION}

The two-spotted spider mite Tetranychus urticae Koch (Acari: Tetranychidae), is an extremely polyphagous pest that has been reported from more than 900 host species and is described as a serious pest of at least 150 economically important agricultural and ornamental plants (Zaher, 1986; Krips, et al., 1998; Zhang, 2003; Mondal \& Ara, 2006). Indeed, temperature is a critical abiotic factor influencing the dynamics of arthropod pests and their natural enemies (Huffaker and Gtierrez 1999). Temperature has distinct effect on the different biological aspects of arthropods, and upper and lower developmental threshold temperatures as well as optimal temperature can be estimated for each pest mite organism and its natural enemies (Roy et al. 2002). Biological knowledge, in particular life table attributes is a significant step to an improved reorganization of the population dynamics of pests. This information may be used as an important mean in planning successful integrated pest management (IPM) program for this spider mite.

The present work aimed to study the different biological aspects of $T$. urticae at five temperatures $\left(15,20,25,30\right.$ and $\left.35^{\circ} \mathrm{C}\right)$ in the laboratory.

\section{MATERIALS AND METHODS}

\section{Mite culture}

The two-spotted spider mite, T. urticae Koch was collected from leaves of castor bean plant, Ricinus communis L. Samples were collected from the farm of Faculty of Agriculture, Mansoura University.

\section{Influence of different temperatures on development of $T$. urticae:}

Leaf discs of $R$ communis, one square inch each, were used as a substrate for rearing newly deposited eggs of $T$. urticae which were singly transferred to leaf discs placed on wet cotton pads in Petri dishes (15 $\mathrm{cm}$ in diameter). T. urticae eggs were separated into five major groups, 30 eggs each, according to the tested temperatures. Five temperatures were tested $\left(15,20,25,30\right.$ and $\left.35 \pm 1^{\circ} \mathrm{C}\right)$ at $70 \pm 5 \% \mathrm{RH}$. Observations on life development were recorded twice a day during mite life span.

\section{Statistical analysis}

Life table parameters were calculated using a BASIC computer program (Abou-Setta et al. 1986) for females reared on various tested temperature degrees. This computer program is based on Birch's method (1948) for the calculation of an animal's life table. Constructing a life table, using rates of agespecific ( $\mathrm{Lx})$, and fecundity $(\mathrm{Mx})$ for each age interval ( $\mathrm{x}$ ) was assessed. The following population growth parameters were determined: the mean generation time $(T)$, gross reproductive rate (GRR) $(=\Sigma \mathrm{Mx})$, the net reproductive rate $\left(\mathrm{R}_{\mathrm{o}}\right)$, the intrinsic rate of increase $\left(\mathrm{r}_{\mathrm{m}}\right)$ and the finite rate of increase $\left(\exp r_{m}\right)$. The doubling time (DT), Cohort Generation Time $\left(T_{c}\right)$, Capacity of increase $\left(r_{c}\right)$ and Annual rate of increase (ARI) were calculated according to Laughlin, 1965; May, 1976 and Carey, 1993. The life tables were prepared from data recorded daily on developmental time (egg to first egg laid), sex ratio, the number of deposited eggs, the fraction of eggs reaching maturity, and the survival of females. Interval of one day was chosen as the age classes for constructing the life table.

\section{RESULTS AND DISCUSSION}

\section{Immature stages:}

Data in Table (1) show that eggs of T. urticae female hatched after 6.65 days at $15^{\circ} \mathrm{C}$, while 20,25 , 30 and $35^{\circ} \mathrm{C}$ clearly accelerated hatching which 
averaged $5.45,3.65,2.60$ and 1.80 days, respectively. Rising temperature had an obvious effect on the development of immature stages where increasing temperature significantly shortened the developmental periods. Sabelis (1981) reported that a female $T$. urticae developed from egg to adult in approximately 6.5 days at $30^{\circ} \mathrm{C}$. Bounfour and Tanigoshi (2001) stated that life cycle of T. urticae was $25.30,16.00,13.9$ and 7.40 days when reared at $15,20,25$ and $30^{\circ} \mathrm{C}$ respectively. Praslicka and Huszar (2004) showed that life cycle of $T$. urticae was fast at $35^{\circ} \mathrm{C}(6.50$ day $)$; while at $15^{\circ} \mathrm{C}$ it took 16.23 days. Also, Osman et al. (2010) stated that life cycle of $T$. urticae was 9.80 days when reared at $28^{\circ} \mathrm{C}$.

\section{Adult stage:}

The pre-oviposition period of $T$. urticae female averaged $5.15,4.50,2.00,1.45$ and 0.70 days; average female laid $49.15,51.9,65.25,53.90$ and 27.9 eggs at $15,20,25,30$ and $35^{\circ} \mathrm{C}$, respectively (Tables $2 \& 3$ ), whereas sex ratio was $0.58,0.61$, $0.64,0.66$ and 0.71 at the same temperature Average fenale lived for $20.45,18.05,10.00,7.65$ and 6.05 days, while, its lifespan averaged 35.40 , $31.00,20.50,15.30$ and 12.35 days at $15,20,25,30$ and $35^{\circ} \mathrm{C}$, respectively.

Saito (1979) showed that the longevity and life span of $T$. urticae female were 19.41 and 29.07 days at $25^{\circ} \mathrm{C}$. Bounfour and Tanigoshi (2001) reported that T. urticae adult female longevity and life span when reared under $15,20,25,30^{\circ} \mathrm{C}$ were 22.00 , $26.90,20.90$ and 17.10 days and $47.30,42.90,34.20$ and 27.9 days, respectively. They noticed that all stages died at $35^{\circ} \mathrm{C}$. Osman et al. (2010) observed that longevity and life span of $T$. urticae adult female was 14.60 and 23.86 days, respectively; when reared at $28^{\circ} \mathrm{C}$. Hazan et al., (1973) recorded lower fecundity of the spider mite at temperatures above $30{ }^{\circ} \mathrm{C}$. Tsai et al., (1989) showed that Tetranychus kanzawi female laid $27.8 \mathrm{eggs}$ at $15^{\circ} \mathrm{C}$ and 76.0 eggs at $30^{\circ} \mathrm{C}$. Shih (1999) observed that T. urticae female laid maximum of 100 eggs in 10 days. He stated that temperature $23-30^{\circ} \mathrm{C}$ was optimal for its development. Bounfour and Tanigoshi (2001) reported that T. urticae fecundity was $38.10,124.7,92.8$ and 121.20 when reared on $15,20,25$ and $30^{\circ} \mathrm{C}$, respectively. Praslicka and
Huszar (2004) noticed that fecundity of T. urticae was highest at a $30^{\circ} \mathrm{C}$ as 89.1 eggs/female, and lowest at $15^{\circ} \mathrm{C}$ as $58.6 \mathrm{eggs} / \mathrm{female}$. The fecundity of female mite increased with temperature increase up to $30^{\circ} \mathrm{C}$, but at $35^{\circ} \mathrm{C}$ it decreased to $71.08 \mathrm{eggs} / \mathrm{female}$. Naher et al., (2008) reported that $T$. urticae fecundity was $58.21,82.46$ and $62.96 \mathrm{eggs} / \mathrm{female}$ in winter, autumn and summer, respectively. Osman et al. (2010) showed that fecundity of $T$. urticae was $64.8 \mathrm{eggs} /$ female at $28{ }^{\circ} \mathrm{C}$.

The relationship between temperature and rate of development in insects and mites is usually calculated as linear, but it is actually curvilinear (Sharpe and De Michele 1977). The simple linear regression between temperature (independent variable $X$ ) and the developmental rate (dependent variable $Y$ ) of $T$. urticae egg indicated $R^{2}=0.948$ and the regression equation as: Developmental rate $(Y)=0.0205 x-0.2007$ Temperature (X) (Fig. 1). $\mathrm{R}^{2}$ values of larva, protonymph, deutonymph, total immatures and life cycle were 0.9102, 0.9232, $0.9013,0.93880 .96$, respectively. The regression equations were $(\mathrm{Y})=0.0152(\mathrm{X})+0.0334$, $(\mathrm{Y})=0.0157(\mathrm{X})+0.1385,(\mathrm{Y})=0.0167(\mathrm{X})+$ $0.1346,(\mathrm{Y})=0.0053(\mathrm{X})+0.0305$ and $(\mathrm{Y})=0.0047$ (X) - 0.0126 for larva, protonymph, deutonymph, total immatures and life cycle, respectively. Also, the value of $\mathrm{R}^{2}$ of preoviposition, oviposition, postoviposition, longevity and life span were $0.8867,0.9612,0.9569,0.969$ and 0.9928 , respectively. The regression equations were $(\mathrm{Y})=0.0528(\mathrm{X})-0.7425,(\mathrm{Y})=0.0074(\mathrm{X})-$ $0.0192,(\mathrm{Y})=0.0356(\mathrm{X})-0.4173,(\mathrm{Y})=0.0062(\mathrm{X})$ - 0.0549 and $(\mathrm{Y})=0.0031(\mathrm{X})-0.0296$ for preoviposition, oviposition, postoviposition, longevity and life span, respectively.

As a result, it was noted that thermal factor had negative relationship with duration of each stage as increasing temperature accelerated development and shortened, longevity and life span of $T$. urticae.

\section{Life table parameters:}

The calculated life table parameters considered were: mean generation time $(T)$, net reproductive rate $\left(\mathrm{R}_{0}\right)$, doubling time $(\mathrm{DT})$, intrinsic rate of

Table (1): Duration in days of developmental stages of Tetranychus urticae ( Koch ) fimale at different temperatures.

\begin{tabular}{|c|c|c|c|c|c|c|}
\hline \multirow{2}{*}{ Tcmp. } & \multicolumn{5}{|c|}{ Developmental stages } & \multirow{2}{*}{ Life cycle } \\
\hline & Egg & Larva & Protonymph & Deutonymph & Total immatures & \\
\hline 15 & $6.65 \pm 0.13$ & $3.35 \pm 0.10$ & $2.50 \pm 0.11$ & $2.45 \pm 0.11$ & $8.30=0.20$ & $14.95+0.26$ \\
\hline 20 & $5.45 \pm 0.15$ & $3.10 \pm 0.06$ & $2.25 \pm 0.09$ & $2.15 \pm 0.08$ & $7.50=0.13$ & $12.95 \pm 0.21$ \\
\hline 25 & $3.65 \pm 0.10$ & $2.70 \pm 0.14$ & $2.10 \pm 0.10$ & $2.05 \pm 0.08$ & $6.85=0.13$ & $10.50 \pm 0.19$ \\
\hline 30 & $2.50 \pm 0.11$ & $2.15 \pm 0.08$ & $1.55 \pm 0.11$ & $1.45 \pm 0.11$ & $5.15=0.16$ & $7.65 \pm 0.22$ \\
\hline 35 & $1.80=0.11$ & $1.65 \pm 0.10$ & $1.45 \pm 0.11$ & $1.40 \pm 0.11$ & $450=0.12$ & $6.30 \pm 0.17$ \\
\hline
\end{tabular}




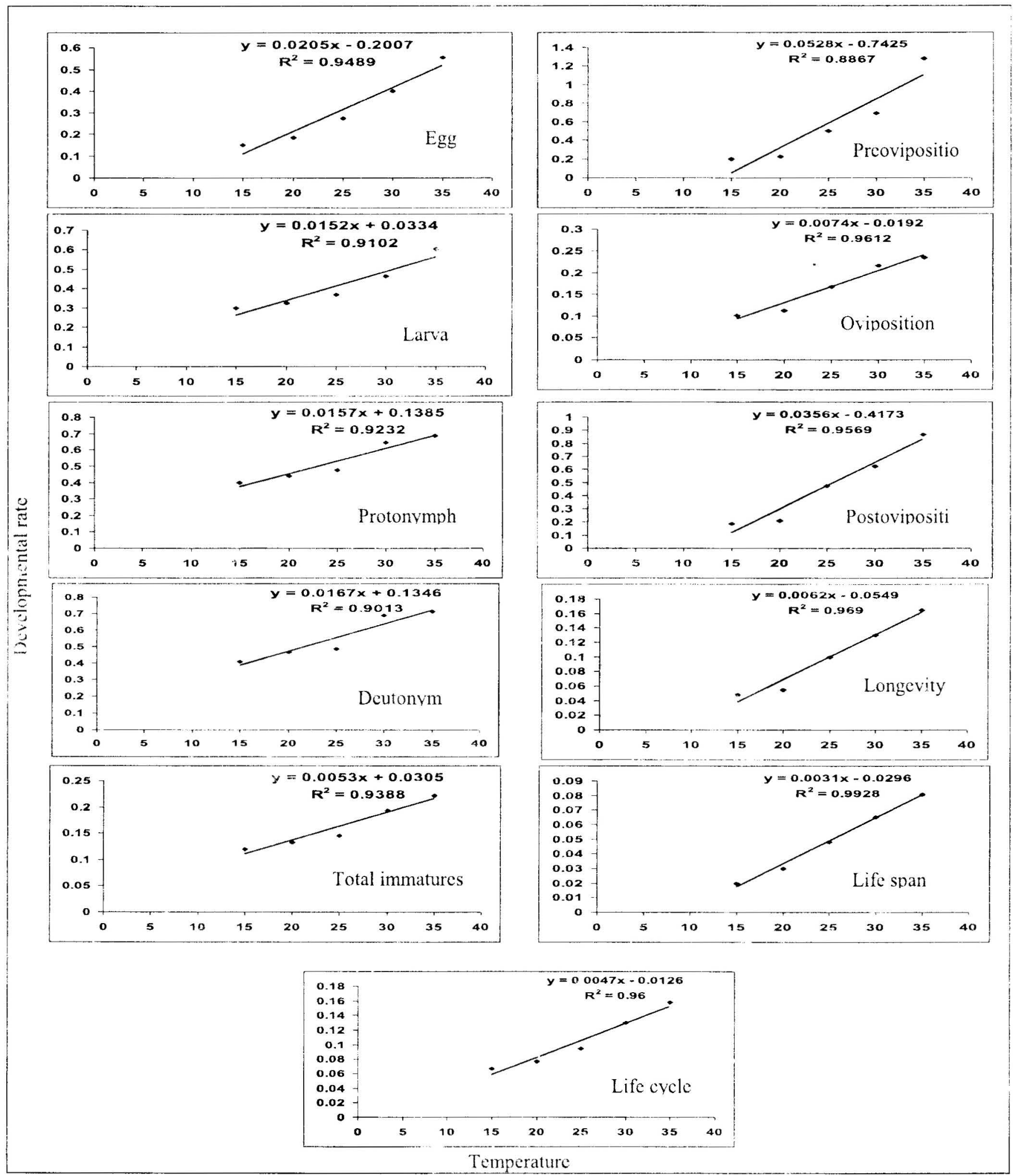

Fig.(1): Linear regression analysis of temperature versus developmental rates of $T$. urticae (Koch) female.

Tathle (2): Duration in days of of Tetranychus urticae (Koch) female at different temperatures

\begin{tabular}{|c|c|c|c|c|c|}
\hline \multirow[t]{2}{*}{$\mathrm{cmp}$. } & \multicolumn{4}{|c|}{ Adult stage } & \multirow{2}{*}{ Life span } \\
\hline & Preoviustion & Oviposition & Postoviposition & Longevity & \\
\hline 5 & 5.0 .16 & $9.90 \pm 0.27$ & $5.35 \pm 0.19$ & $20.45 \pm 0.35$ & $35.40=0.43$ \\
\hline 30 & $450=0.13$ & $8.80 \pm 0.15$ & $4.75 \pm 0.12$ & $18.05 \pm 0.24$ & $31.00 \pm 0.30$ \\
\hline 25 & $00 \quad 12$ & $5.95 \pm 21$ & $2.10 \pm 0.16$ & $10.00 \pm 0.20$ & $20.50 \pm 0.26$ \\
\hline 30 & $\therefore 4 \cdot 0.1]$ & $4.60 \pm 0.16$ & $1.60 \pm 0.5$ & $7.65 \pm 0.25$ & $15.30 \pm 0.30$ \\
\hline 55 & $y=1.12$ & $4.25 \pm 0.14$ & $1.15=0.15$ & $6.05 \pm 0.30$ & $12.35 \pm 0.31$ \\
\hline
\end{tabular}


Table (3): Effect of different temperatures on the life table parameters of Tetranychus urticae (Koch)

\begin{tabular}{ccccccccccc}
\hline $\begin{array}{c}\text { Temp. } \\
{ }^{\circ} \mathrm{C}\end{array}$ & $\begin{array}{c}\text { Mean Total } \\
\text { Fecundity }\end{array}$ & $\mathrm{R}_{\mathrm{o}}$ & $\mathrm{T}$ & $\mathrm{r}_{\mathrm{m}}$ & $\exp \mathrm{r}_{\mathrm{m}}$ & $\mathrm{GRR}$ & $\mathrm{DT}$ & $\mathrm{T}_{\mathrm{c}}$ & $\mathrm{r}_{\mathrm{c}}$ & ARI \\
\hline 15 & $49.15 \pm 1.88$ & 22.82 & 20.25 & 0.154 & 1.166 & 23.07 & 4.46 & 21.01 & 0.148 & $3.846 \times 10^{24}$ \\
\hline 20 & $51.90 \pm 0.92$ & 27.02 & 18.34 & 0.179 & 1.196 & 27.30 & 3.83 & 18.87 & 0.174 & $3.961 \times 10^{28}$ \\
\hline 25 & $65.25 \pm 2.09$ & 27.84 & 14.02 & 0.237 & 1.267 & 28.19 & 2.91 & 14.38 & 0.231 & $5.730 \times 10^{28}$ \\
\hline 30 & $53.90 \pm 1.67$ & 22.73 & 10.28 & 0.303 & 1.355 & 23.84 & 2.27 & 10.59 & 0.294 & $1.799 \times 10^{48}$ \\
\hline 35 & $27.90 \pm 0.89$ & 9.79 & 8.77 & 0.259 & 1.296 & 12.91 & 2.65 & 9.00 & 0.253 & $2.881 \times 10^{41}$ \\
\hline
\end{tabular}

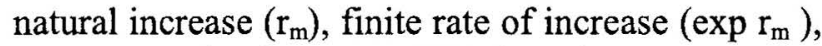
gross reproductive rate (GRR) cohort generation time $\left(\mathrm{T}_{\mathrm{c}}\right)$, capacity of increase $\left(\mathrm{r}_{\mathrm{c}}\right)$ and annual rate of increase (ARI) (Table 3).

Concerning life table parameters of $T$. urticae, the present study indicated that thermal factor has a great influence. $R_{0}$ values averaged 22.842, 27.024, $27.846,22.738$ and 9.790 when $T$. urticae was kept at $15,20,25,30$ and $35^{\circ} \mathrm{C}$, respectively. Also, the mean generation time $(\mathrm{T})$ averaged $20.259,18.345$, $14.029,10.282$ and 8.775 when $T$. urticae individuals were kept at the same temperatures. From previous results, it could be noticed that $T$. urticae population could multiply $22.842,27.024$, $27.846,22.738$ and 9.790 times in a generation time $20.259,18.345,14.029,10.282$ and 8.775 (Table 3).

Bounfour and Tanigoshi (2001) recorded that the net reproductive rate $\left(R_{0}\right)$ and the mean generation time (T) of T. urticae were $24.66,80.99,54.86$ and 86.01 and $38.29,26.48,21.25$ and 13.86 days when reared at $15,20,25$ and $30{ }^{\circ} \mathrm{C}$, respectively. Razmjou et al., (2009) reported that $\mathrm{R}_{0}$ and $\mathrm{T}$ ranged between 12.57 and 30.51 and 10.66 and 11.66 days when reared $T$. urticae at $25{ }^{\circ} \mathrm{C}$ on five bean cultivars, whereas, Osman et al. (2010) showed that $\mathrm{R}_{0}$ and $\mathrm{T}$ of $T$. urticae were 36.98 and 16.19 at $28^{\circ} \mathrm{C}$.

The intrinsic rate of natural increase $\left(r_{m}\right)$ is a key demographic parameter useful for predicting the population growth potential of an animal under given environmental conditions, as it reflects an overall effect on development, reproduction and survival (Southwood and Handerson 2000). Estimates of $r_{m}$ are difficult to compare between studies, because of genetic variation, differences in rearing methods, other environmental conditions, and variable assumptions entering these estimations (Roy et al. 2002). Temperature is a key determinant of $r_{m}$ as developmental period, fertility and other life history parameters (Birch, 1948).

Accordingly, data in Table (3) showed that $r_{m}$ values were $0.1543,0.179,0.237,0.303$ and 0.259 individuales/female/day when $T$. urticae was reared at $15,20,25,30$ and $35^{\circ} \mathrm{C}$, respectively, Therefore, it can be concluded that the net rate of natural increase was highly influenced by thermal factor. Sabelis (1985) showed that spider mites (Acari: Tetranychidae) are a well documented example of plant-feeding pests with high $r_{m}$ values and are notorious for their ability to develop damaging outbreaks on a wide range of cultivated crops. The highest reported $r_{m}$ for tetranychid mites was 0.48 for the Banks grass mite, Oligonychus pratensis (Banks) at $36^{\circ} \mathrm{C}$ (Perring et al. 1984). Sabelis (1991), in an extensive review of life-history parameters of tetranychid mites, found the $r_{m}$ values for Tetranychus mites ranged from 0.200 to 0.336 day $^{-1}$ at $25^{\circ} \mathrm{C}$. Bounfour and Tanigoshi (2001) recorded that $r_{m}$ value of $T$. urticae at $15,20,25$ and $30^{\circ} \mathrm{C}$ was $0.084,0.166,0.188$ and 0.321 respectively. Osman et al. (2010) reported that $\mathrm{r}_{\mathrm{m}}$ value of $T$. urticae was 0.222 individuales/female/day.

The doubling time (DT) of $T$. urticae was $4.46,3.83,2.91,2.27$ and 2.65. Also, gross reproductive rate (GRR) was 23.07, 27.30, $28.19,23.84$ and 12.91 at the same temperatures.

In the present study, the cohort generation time $\left(\mathrm{T}_{\mathrm{c}}\right)$ of $T$. urticae was 21.01, 18.87, 14.38, 10.59 and 9.00 , while capacity of increase $\left(r_{c}\right)$ recorded $0.148,0.174,0.231,0.294$ and 0.253 . Also, annual rate of increase was (ARI) $3.846 \times 10^{24}$, $3.961 \times 10^{28}, 5.730 \times 10^{28}, 1.799 \times 10^{48}$ and $2.88 \times 10^{41}$ at $15,20,25,30$ and $35^{\circ} \mathrm{C}$, respectively.

Hoque et al. (2008) reported that $\left(\mathrm{T}_{\mathrm{c}}\right)$ and $\left(\mathrm{r}_{\mathrm{c}}\right)$ of T. urticae were $13.057,15.934 \& 28.972$ and $0.1676,0.1735 \& 0.0544$ in summer, autumn and winter seasons, respectively. Bounfour and Tanigoshi (2001) noticed that $\left(\mathrm{T}_{\mathrm{c}}\right)$ and $\left(\mathrm{r}_{\mathrm{c}}\right)$ of $T$. urticae when reared under $15,20,25,30^{\circ} \mathrm{C}$ were $39.2829 .5322 .97 \& 17.19$ days and $0.082,0.149$, $0.174 \& 0.259$, respectively. Osman et al. (2010) showed that $\left(\mathrm{T}_{\mathrm{c}}\right),\left(\mathrm{r}_{\mathrm{c}}\right)$ and $(\mathrm{ARI})$ of $T$. urticae were $17.20,0.209$ and $2.13 \times 10^{35}$ at $28^{\circ} \mathrm{C}$.

The afor-mentioned results revealed that thermal factor has a great influence on development and life table parameters of $T$. urticae. 


\section{REFERENCES}

Abou-Setta, M. M. and Childers, C. C., 1986. Life 48: a BASIC computer program to calculate life table parameters for an insect or mite species. Fla. Entomol. 69: 690-697

Birch, L. C., 1948. The intrinsic rate of natural increase of an insect population. J. Anim. Ecol., 17: $15-26$.

Bonato, O., 1999. The effect of temperature on life history parameters of Tetranychus evansi (Acari: Tetranychidae). Exp. Appl. Acarol. 23:11-19.

Bounfour, M. and Tanigoshi, L. K., 2001. Effect of temperature on development and demographic parameters of Tetranychus urticae and Eotetranychus carpini borealis (Acari: Tetranychidae). Ann. Entomol. Soc. Am. 94 (3):400-404

Carey, J. R., 1993. Applied demography for biologists with special emphasis on insects. Oxford University Press, New York. 266 pp.

Ferrero, M.; de Moraes, G. J.; Kreiter, S.; Tixier, M. S. and Knapp, M., 2007. Life tables of the predatory mite Phytoseiulus longipes feeding on Tetranychus evansi at four temperatures (Acari: Phytoseiidae, Tetranychidae). Exp. Appl. Acarol. 41:45-53

Hazan, A.; Gerson, V. and Tahori, A. S., 1973. Life history and life tables of the carmine spider mite. Acarologia, 15: 414-440.

Hoque, M. F.; Islam, W. and Khalequzzaman, M., 2008. Life tables of two-spotted spider mite Tetranychus urticae Koch (Acari: Tetranychidae) and its predator Phytoseiulus persimilis Athias-Henriot (Acari: Phytoseiidae). J. Bio. Sci. 16: $1-10$

Huffaker, C. B. and Gutierrez, A. P. 1999. Ecological Entomology. 2nd ed. Wiley, New York. $756 \mathrm{pp}$.

Krips, O. E. ; Witul, A. ; Willems, P. E. L. and Dicke, M., 1998. Intrinsic rate of population increase of the spider mite Tetranychus urticae on the ornamental crop gerbera: intra species variation in host plant and herbivore. Entomol. Exp. Appl. 89:159-168.

Laing, J. E., 1969. Life history and life table of Tetranychus urticae Koch. Acarologia 11: 33-42.

Laughlin, R., 1965. Capacity for increase: a useful population statistic. J. of Anim. Ecology, 34: 77-91.

May, R. M., 1976. Estimating r: a pedagogical note. American Naturalist, 110: 496-9.

Mondal, M. and Ara, N., 2006. Biology and fecundity of the two-spotted spider mite, Tetranychus urticae Koch. (Acari: Tetranychidae) under laboratory conditions. J. Life Earth Sci., 1(2): 43-47
Naher, N.; Islam, M. W.; Khalequzzaman, M. and Haque, M. M., 2008. Study on the developmental stages of spider mite (Tetranychus urticae Koch) infesting country bean. J. bio-sci. 16: 109-114.

Osman, M. A., Abou Elella, G. M. and Tawfik, A. A., 2010. Role of four phytoseiid mite species and acarophagous ladybird, Stethorus gilvifrons (Mulsant) as bioagents of the two spotted spider mite Tetranychus urticae Koch. Acarines, 4: 47-55.

Perring, T. M. ; Holtzer, T. O.; Kalisch, J. A. and Norman, J. M.,

1984. Temperature and humidity effects on ovipositional rates, fecundity, and longevity of adult female Banks grass mites (Acari: Tetranychidae). Ann. Entomol. Soc. Am. 77: 581-586.

Praslicka, J. and Huszar, J., 2004. Influence of temperature and host plants on the development and fecundity of the spider mite Tetranychus urticae (Acarina: Tetranychidae). Plant Protect. Sci., 40: 141-144.

Razmjou, J.; Vorburger, C.; Tavakkoli, H. and Fallahi, A., 2009. Comparative population growth parameters of the two-spotted spider mite, Tetranychus urticae Koch (Acari: Tetranychidae), on different common bean cultivars. Systematic \& Applied Acarology, 14: 83-90.

Roy, M.; Brodeur, J. and Cloutier, C., 2002. Relationship between

temperature and developmental rate of Stethorus punctillum (Coleoptera: Coccinellidae) and its prey Tetranychus medanieli (Acarina: Tetranychidae). Environ. Entomol., 31:177-187

Roy, M., Brodeur, J. and Cloutier, C., 2003. Effect of temperature on intrinsic rates of natural increase $\left(\mathrm{r}_{\mathrm{m}}\right)$ of a coccinellid and its spider mite prey. BioControl. 48, 57-72.

Sabelis, M.W., 1981. Biological control of twospotted spider mites using phytoseiid predators. Part 1. Modeling the predator-prey interaction at the individual level. Agricultural Research Reports No. 910. Wageningen.

Sabelis, M.W., 1985. Reproductive strategies. In: Helle, W. and Sabelis, M.W. (eds) Spider mites: their biology, natural enemies and control. volume 1A. Elsevier Science Publishers BV, Amsterdam, pp 265-278.

Sabelis, M.W., 1991. Life-history evolution of spider mites. In: Schulster, R. and Murphy, P. W. (eds) The acari. reproduction, development and life-history strategies. Chapman and Hall, London, pp 23-49.

Saito, y., 1979. Comparative studies on life histories of three species of spider mites (Acarina: Tetranychidae). Appl. Ent. Zool. 14 (1):83-94. 
Sharpe, J. H. and De Michele, D. W., 1977. Reaction kinetics of poikilotherm development. J. Theor. Biol. 64: $649-670$.

Shih, C. I. T., 1999 Population ecology and its application on tetranychid and phytoseiid mite. Chinese J. Entomol. 126: 25-48.

Southwood, R. and Handerson, P. A., 2000. Ecological Methods, Third Edition. Blackwell Publishing. 592 pp.

Tsai, S. M; Kung, K. S. and Shih, C. I. T., 1989. The effect of temperature on life history and population parameters of kanzawa spider mite,
Tetranychus kanzawai Kishida (Acari: Tetranychidae) on tea. Plant Prot. Bull. Taiwan 31(2): 119-130.

Zaher, M. A., 1986. Survey and ecological studies on phytophagous, predaceous and soil mites in Egypt. I: phytophagous mites in Egypt (Nile Valley and Delta). PI 480 Programme. USA Project No. EG. ARS, 30. Grant. No, FG, Eg., 139. $228 \mathrm{pp}$.

Zhang, Z. Q., 2003. Mites of greenhouse. Identification, biology and control. CABI Pub., 244 pp. 